\title{
An accuracy assessment of European Soil Sealing Dataset (SSL2009): Stara Miłosna area, Poland - a case study
}

Abstract

The purpose of the undertaken survey is to assess the accuracy of the SSE2009, based on a reference dataset. The dataset contains 3,600 samples with the same spatial resolution as the final Soil Sealing Layer product and covers a rectangle of $36 \mathrm{~km}^{2}$. The basis for assessing the accuracy was the photointerpretation of the orthophotomap. The overall accuracy with data division into 6 classes amounted to $65 \%$; while divided into 2 classes: sealed and non-sealed reached 95\%. The evaluation results accuracy may form the basis for future improvements in evaluation methods impervious surface.

\section{Keywords}

Accuracy of soil sealing layer • impervious surfaces $\bullet$ land use $\bullet$ sub-urban area

(C) University of Warsaw - Faculty of Geography and Regional Studies
Piotr Pabjanek ${ }^{1}$, Małgorzata Krówczyńska ${ }^{1,2}$, Ewa Wilk ${ }^{1,2}$, Michał Miecznikowski ${ }^{1}$,

'University of Warsaw, Faculty of Geography and Regional Studies, Department of Geoinformatics, Cartography and Remote Sensing, Warsaw, Poland;

${ }^{2}$ WGS84 Polska Sp. z o.o., Milanówek, Poland

e-mail: p.pabjanek@uw.edu.pl; mkrowczynska@uw.edu.pl; ewa.wilk@student.uw.edu.pl; m.miecznikowski@student.uw.edu.pl

Received: 29 April 2016

Accepted: 31 August 2016

\section{Introduction}

The soil sealing level, or the percentage of impervious surfaces, is an important factor in environmental sciences. Surfaces of this type directly influence the natural water cycle and affect the energy balance of the area. The hydrological regime is influenced by the degree of soil sealing and the spatial pattern; the connectivity between impervious patches necessitates the implementation of remote sensing techniques. Impervious surfaces can also be treated as a reliable indicator of anthropopressure on the natural environment (Arnold \& Gibbons 1996, Weng 2011). Monitoring of the soil sealing level is an important issue where urban sprawl is concerned (Johnson 2001).

The literature provides a variety of definitions of impervious surfaces. Most of them are based on the definition given by Arnold and Gibbons (1996): Impervious surfaces can be defined as any material that prevents the infiltration of water into the soil. Some of the definitions emphasise the urban genesis of the materials (e.g. Bauer et al. 2004, Drzewiecki \& Wróbel 2007, Hurbanek et al. 2010). For the purposes of this research, the definition of the EEA, presented in the instructions for the validation of the Soil Sealing Layer (SSL), was adopted (Maucha et al. 2010): Impervious surfaces are mainly artificial structures - such as pavements (roads, sidewalks, driveways and parking lots) that are covered by impenetrable materials, such as asphalt, concrete, brick, stone and rooftops.

Soil sealing is directly associated with the degree of urbanization. The most significant effects are visible in areas where the level of imperviousness is high - mainly cities and industrial areas - but as much as $10 \%$ of impervious surfaces can cause a change in the natural conditions of the environment (Arnold \& Gibbons 1996, Flinker 2010). Therefore, it is difficult to determine the consequences of soil sealing. Even though impervious surfaces do not cause pollution, they provide a route for urban pollution to flow with rainwater through the sewerage system and join the natural water cycle. In this way, a lot of particles, metals, pesticides and herbicides get into the natural environment (Arnold \& Gibbons 1996, Flinker 2010).

One of the most evident effects of this phenomenon is the increase in the average temperature in the lowest atmospheric layer in urban areas in comparison with external areas (i.e. urban heat island) (Grimmond 1998). Concrete and asphalt, typical urban impervious materials, are characterized by an increased heat capacity (Oke 1973). These surfaces accumulate energy during the day and radiate it during the night. Another consequence is evapotranspiration reduction, which also contributes to the rise in urban temperature (Grimmond 1998).

The basin sealing level is an important indicator of the functioning of the water basin. The amount of impervious surfaces in the basin area influences the water-flow in it (Borowiec \& Hamerla 2013). Hence, the analysis of the urban basin can be used in spatial planning and sewerage system development (Skotnicki \& Sowiński 2011). Maps of impervious surfaces can and should also be used in spatial planning and urban management.

There are many methods for preparing digital land cover maps. The choice of the method depends on numerous factors: the purpose of mapping, the amount and weight of the data, the expected accuracy, the costs of the project, etc. One of the most frequently used methods is photogrammetry and remote sensing of the satellite imagery (Stocker 1998). The first publications in the field which used remotely sensed data appeared in the 1970s (Drzewiecki \& Wróbel 2007). 
Another noteworthy issue in land cover mapping is the accuracy of the results in comparison to satellite imagery (Edwards \& Moisen 1998, Scepan 1999, Atkinson \& Foody Curran 2000, Iwaniak et al. 2002). Errors in thematic mapping appear due to the low quality of the imagery (e.g. cloud cover), the choice of the classification method and the temporal gap between classification and reference data (Congalton \& Green 1993). If the satellite imagery used is of low spatial resolution, there is a possibility of heterogeneity of the spectral information registered by the scanner. In remote sensing data classification, a target of $85 \%$ is often used as the standard for thematic mapping (Foody 2008).

Soil Sealing is the first high-resolution Land Monitoring layer of the European Environment Agency (EEA) covering Europe; it was adopted for the characterisation of the human impact on the environment (Maucha et. al. 2010). It was produced in 20062008 within the GMES Fast Track Service of the Land Monitoring programme (now Copernicus) in order to provide a source of information for high spatial resolution data (Hurbanek et al. 2010b).

According to the definition provided by the EEA, imperviousness (or the degree of soil sealing) is estimated in relation to the pixel area, and built-up areas at the 1 ha level are defined by the average sealing degree per 1 ha unit above $80 \%$ (EEA 2006).

For the purpose of creating the Soil Sealing Layer, orthorectified satellite data coverage for Europe (Image2006), acquired primarily in the reference year 2006 (+/- 1 year), covering two dates, and using the SPOT 4 and 5 (HRVIR) and IRS-P6 LISS-III sensors, were provided by the European Space Agency (ESA). The same imagery was used for the CORINE Land Cover 2006 update. The imagery used had a spatial resolution of 20 $\mathrm{m}$, resampled with 4 spectral bands and maximum $5 \%$ cloud coverage, performed on 2 dates at least 6 weeks apart, from the respective scene selected for the first coverage, as well as the metadata for each scene. Supervised classification of the builtup areas, followed by the visual improvement of classification results and derivation of the degree of soil sealing based on the calibrated NDVI, was implemented with a pixel resolution of $20 \mathrm{~m}$ x 20 m (Maucha et al. 2010).

The development of the Soil Sealing database covering 38 European countries was applied in two stages:

I. Initial Soil Sealing (ISS) data on the basis of EEA 2006 tender specifications, an intermediate layer was created with the degree of imperviousness at $20 \mathrm{~m}$ pixel resolution;

II. Soil Sealing Enhancement (SSE) data, consisting of a quality assured and validated 1 ha layer of built-up areas (cells with imperviousness $\geq 80 \%$ ) with an overall classification accuracy per hectare (based on a $100 \mathrm{~m} \times 100 \mathrm{~m}$ grid) of built-up and non-built-up areas of at least $85 \%$ (EEA 2006). SSE constitutes an improvement of the ISS database based on the evaluation of ISS data by some Member States.

Data on imperviousness is provided through the Copernicus project website.

The accuracy assessment of SSL2006 was performed under the auspices of the EEA and presented in a final report by Maucha et al. (2010).

The update data for 2009 is provided by the EEA, and produced by the Copernicus Land Monitoring Services and Geoland-2. The processing scheme is based on the experiences from 2006, and the results of the product validation were implemented in 2009. The criteria set for the product stated that statistical validation was to be carried out on the $100 \mathrm{~m} \times 100$ $\mathrm{m}$ data, and the minimum overall accuracy should be $85 \%$ with $>90 \%$ as the overall target. The final product consisted of two products: a status layer for 2009 , as well as an imperviousness density change layer between 2009 and 2006, and based on the already existing imperviousness product for the earlier reference year (EEA 2015).

The accuracy assessment of SSL2009 was performed for Slovakia by Hurbanek et al. (2010b). It was stated that, while the overall accuracy of the product fulfils the criteria set, the classification procedure tends to overestimate the medium and higher soil sealing values, and underestimates medium and smaller soil sealing values. This may lead to the overestimation of the proportion of impervious surfaces in urban areas and their underestimation or omission in small rural settlements (Hurbanek et al. 2010b).

The purpose of the undertaken survey is to assess the accuracy of SSL2009, based on a reference dataset for Stara Miłosna, Warsaw area, Poland.

\section{Study area}

For this research, an accuracy assessment was carried out in an area of $36 \mathrm{~km}^{2}(6 \times 6 \mathrm{~km})$ covering the settlement of Stara Miłosna and its surroundings (sub-urban area of Warsaw, Poland). This settlement used to be an independent city and was joined with the administrative borders of the Polish capital in 2002. Nowadays, Stara Miłosna belongs to the Wesoła district of Warsaw. The research area also contains parts of the Wawer district in the south, and an area outside Warsaw in the east.

The diversity of the land cover types allows for the assessment of the accuracy of the classification under different conditions. According to CORINE Land Cover 2006, the area contains 8 classes of land cover from the level 3 legend. The largest area belongs to coniferous forest $(38.1 \%)$. Altogether, forests and semi-natural surfaces cover $59.7 \%$ of the whole study area. $21.3 \%$ is used for agricultural purposes, and $19 \%$ of the study area is formed of artificial surfaces. The area contains forests belonging to the Masovian Landscape Park and is characterized by a variety of built-up areas: discontinuous urban fabric and industrial/commercial units, as well as green urban areas (Figure 1).

\section{Methods}

The method used in the work was originally developed by Maucha and Buttner (2008) and afterwards used by Hurbanek et al. (2010a). The reference dataset was made on the basis of the photointerpretation of the orthophotomap and the assignment of a sealing value to each analysed point. The reference dataset had to fulfil a set of criteria given in the tender specifications by the EEA: the area had to cover a diversity of land cover types, the time gap between the SSL and reference data had to be a maximum of 1 year, and the cloud cover could be a maximum

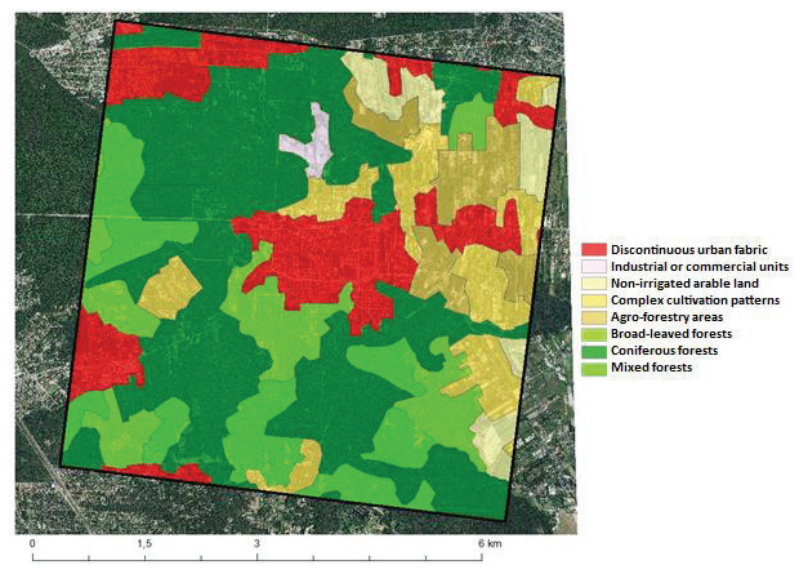

Figure 1. Study area. 
of $5 \%$ (EEA 2006). There was no cloud cover for the area of Stara Miłosna on the orthophotomap used in the undertaken survey.

The survey used the 2008 orthophotomap acquired by the City of Warsaw, published by Warsaw Web Map Service (WMS); it was linked with the WMS from the Polish National Geoportal with the use of ArcGIS 10.0 software. The spatial resolution of the data used was $0.25 \mathrm{~m}$; this was used as reference data due to its very high resolution, replacing an in-situ survey. The orthophotomap was presented in the ETRS89/Poland CS92 (EPSG:2180) coordinate system.

The first stage of the work involved the preparation of the grid for interpretation. The reference area was divided into squares of $100 \mathrm{~m} \times 100 \mathrm{~m}$ each; each sample contained 100 points regularly distributed every $10 \mathrm{~m}$ (Figure 2). The samples were located just within the borders of the SSL points. Photointerpretation made it possible to assign each cell to one of the two defined classes: sealed or natural.

Sealed surfaces contained artificial structures, such as roofing, roads, parking lots, pavements, etc. Non-sealed surfaces were mainly covered with vegetation (e.g. forests, agricultural areas, lawns, etc.)

The sealing values in the samples were calculated by totalling the point values within each sample. At this stage, the reference data consisted of $100 \mathrm{~m} \times 100 \mathrm{~m}$ cells with an aggregated sealing percentage. Next, the sealing values were divided into six intervals: $0 \%, 1-29 \%, 30-49 \%, 50-79 \%, 80-99 \%$ and $100 \%$; and two intervals: $0-79 \%, 80-100 \%$ (it was assumed that the latter percentage group represents built-up areas), as in the SSL validation instructions (Maucha et al. 2010). The obtained data was compared with the SSL results: the two datasets were placed together and the percentage of soil sealing in each sample could be compared for two intervals (built-up and non-built-up classes) and six intervals (as mentioned: $0 \%, 1-29 \%, 30-49 \%, 50-79 \%$, $80-99 \%$ and $100 \%$ ).

Finally, the reference data values were subtracted from the SSE data and the results were presented in a raster image. A confusion matrix was developed in order to calculate the following statistics: commission error, omission error, user's and producer's accuracy for each class, and overall accuracy (Foody 2002). Additionally, the Cohen's kappa coefficient was calculated.

\section{Results}

Only 9 out of the 3,600 analysed cells were assigned a level of imperviousness above $80 \%$. None of the cells were attributed a value of imperviousness of $100 \%$. The highest value was $95 \%$, which was derived for commercial units. According to the SSE, there were 207 cells with a surface impervious proportion of over $80 \%$, including 10 with an imperviousness level of $100 \%$, and only 6 of them were classified correctly; this may be an indicator of the considerable overstatement of this class. 3,390 out of 3,591 cells were correctly classified in un-built areas $(0-79 \%$ imperviousness); the overall accuracy was $94.3 \%$, but the Cohen's kappa coefficient is $5.1 \%$ (Table 1 , Table 2).

When divided into 6 classes, the best classification results were obtained for non-sealed cells. Underestimation was determined for the class of $1-29 \%$ imperviousness; these cells were often classified as non-sealed. Fairly large discrepancies appear for the two classes with a medium proportion of impervious surfaces $(30-49 \%$ and $50-79 \%)$, as the under- and overestimation, respectively. The overall accuracy calculated for the six intervals was $64.94 \%$; the Cohen's kappa coefficient was 40.13\% (Table 3, Table 4).

The proportion of properly classified cells decreases from the class of $1-29 \%$ imperviousness to the class of $100 \%$ imperviousness (Table 4), which is seen in the increased spread of the points on the scatterplot (Figure 3).

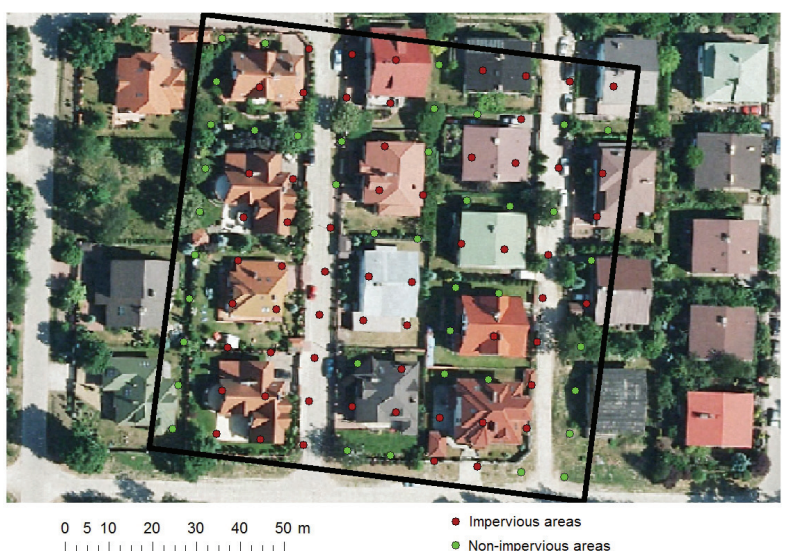

Figure 2. Example of sample with points regularly distributed every $10 \mathrm{~m}$.

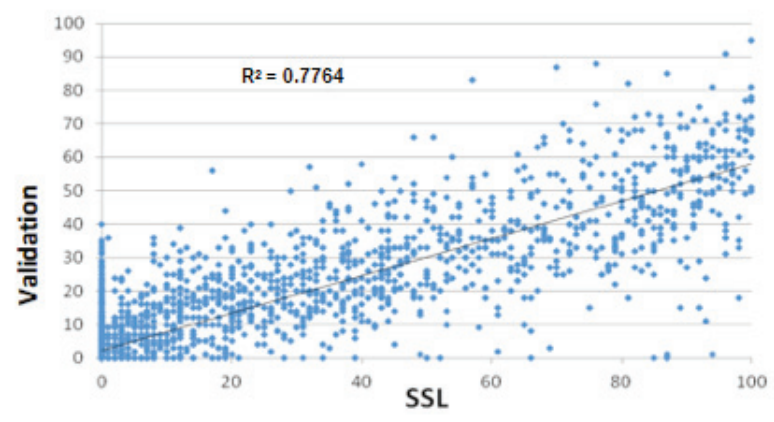

Figure 3. Relationship between SSL and validation results.

Table 1. Confusion matrix for two intervals: sealed and nonsealed surfaces.

\begin{tabular}{|c|c|c|c|c|}
\hline \multirow{4}{*}{ Validation } & \multicolumn{4}{|c|}{ SSL } \\
\cline { 2 - 5 } & & $\mathbf{0 - 7 9} \%$ & $\mathbf{8 0 - 1 0 0 \%}$ & $\Sigma$ \\
\cline { 2 - 5 } & $\mathbf{0 - 7 9 \%}$ & 3,390 & 201 & 3,591 \\
\cline { 2 - 5 } & $\mathbf{8 0 - 1 0 0 \%}$ & 3 & 6 & 9 \\
\cline { 2 - 5 } & $\Sigma$ & 3,393 & 207 & 3,600 \\
\hline
\end{tabular}

Table 2. Accuracy results for two intervals: sealed and nonsealed surfaces.

\begin{tabular}{|c|c|c|}
\hline & $\mathbf{0 - 7 9} \%$ & $\mathbf{8 0 - 1 0 0 \%}$ \\
\hline User's accuracy & $99.91 \%$ & $2.90 \%$ \\
\hline Commission error & $0.09 \%$ & $97.10 \%$ \\
\hline Producer's accuracy & $94.40 \%$ & $66.67 \%$ \\
\hline Omission error & $5.60 \%$ & $33.33 \%$ \\
\hline
\end{tabular}

Discussion and conclusion

The overall accuracy of the results of the Soil Sealing Enhancement product were assessed during a two-stage survey. The degree of accuracy of the Soil Sealing Layer (SSL) constitutes a major question: whether it is sufficient to evaluate the surface 
MISCELLANEA GEOGRAPHICA - REGIONAL STUDIES ON DEVELOPMENT

Vol. 20 • No. 4 • 2016 • pp. 59-63 • ISSN: 2084-6118 • DOI: 10.1515/mgrsd-2016-0019

Table 3. Confusion matrix for six intervals.

\begin{tabular}{|c|c|c|c|c|c|c|c|c|}
\hline \multirow{9}{*}{\begin{tabular}{|l} 
\\
Validation \\
\end{tabular}} & \multicolumn{8}{|c|}{ SSL } \\
\hline & & $0 \%$ & $1-29 \%$ & $30-49 \%$ & $50-79 \%$ & $80-99 \%$ & $100 \%$ & $\Sigma$ \\
\hline & $0 \%$ & 1,832 & 60 & 3 & 3 & 2 & 0 & 1,900 \\
\hline & $1-29 \%$ & 615 & 396 & 148 & 62 & 15 & 0 & 1,236 \\
\hline & $30-49 \%$ & 6 & 30 & 69 & 118 & 68 & 0 & 291 \\
\hline & $50-79 \%$ & 0 & 5 & 6 & 37 & 108 & 8 & 164 \\
\hline & $80-99 \%$ & 0 & 0 & 0 & 3 & 4 & 2 & 9 \\
\hline & $100 \%$ & 0 & 0 & 0 & 0 & 0 & 0 & 0 \\
\hline & $\Sigma$ & 2,453 & 491 & 226 & 223 & 197 & 10 & 3,600 \\
\hline
\end{tabular}

Table 4. Accuracy results for six intervals.

\begin{tabular}{|c|c|c|c|c|c|c|}
\hline & $\mathbf{0} \%$ & $\mathbf{1 - 2 9} \%$ & $\mathbf{3 0 - 4 9 \%}$ & $\mathbf{5 0 - 7 9 \%}$ & $\mathbf{8 0 - 9 9} \%$ & $\mathbf{1 0 0 \%}$ \\
\hline User's accuracy & $74.68 \%$ & $80.65 \%$ & $30.53 \%$ & $16.59 \%$ & $2.03 \%$ & $0 \%$ \\
\hline Commission error & $25.32 \%$ & $19.35 \%$ & $69.47 \%$ & $83.41 \%$ & $97.97 \%$ & $100 \%$ \\
\hline Producer's accuracy & $96.42 \%$ & $32.04 \%$ & $23.71 \%$ & $22.56 \%$ & $44.44 \%$ & $100 \%$ \\
\hline Omission error & $3.58 \%$ & $67.96 \%$ & $76.29 \%$ & $77.44 \%$ & $55.56 \%$ & $0 \%$ \\
\hline
\end{tabular}

imperviousness and hydrological modelling. The overall accuracy for two classes - built-up and non-built-up - was $94.3 \%$, with the Cohen's kappa coefficient presenting a significantly low value. After the division of the dataset into six intervals, the overall accuracy dropped to $64.94 \%$, but the Cohen's kappa coefficient rose to $40.13 \%$. The areas with a degree of imperviousness between $50 \%$ and $100 \%$ had the greatest impact on the disparity between the SSL and validation maps; and also decreased the accuracy of the product. Similar conclusions were derived during the accuracy assessment of SSL2009 for Slovakia (Hurbanek et al. 2010).

The accuracy result of SSL2009 is overestimated due to the domination in the cells' volume of the non-built-up class; a substantial area in the research dataset for Stara Miłosna is covered with forests. The producer's accuracy for the built-up class is significantly lower than for the non-built-up class. The user's accuracy reaches the highest value in the interval of $1-29 \%$ imperviousness; it is very similar to the non-built-up class and decreases with the increasing level of imperviousness. The $100 \%$ producer's accuracy for the non-built-up class is a result of the lack of validation samples in the reference data.

Trodden and ridden areas presented a problem in the classification process, since they have been transformed by long-term, repetitive human actions (semi-sealed surfaces), which often cover industrial areas, dirt-roads or dirt-courtyards typical for the detached housing of suburbia. Also problematic were areas covered with bare soil or low vegetation cover, which tend to have a spectral response similar to artificial surfaces. Cells with a large proportion of such areas may be misclassified. Classification errors may also result from the low spatial resolution of source data. The validation results indicate the possibility of a local calibration and correction of the area with the built-up and non-built class, even based on a regression analysis between

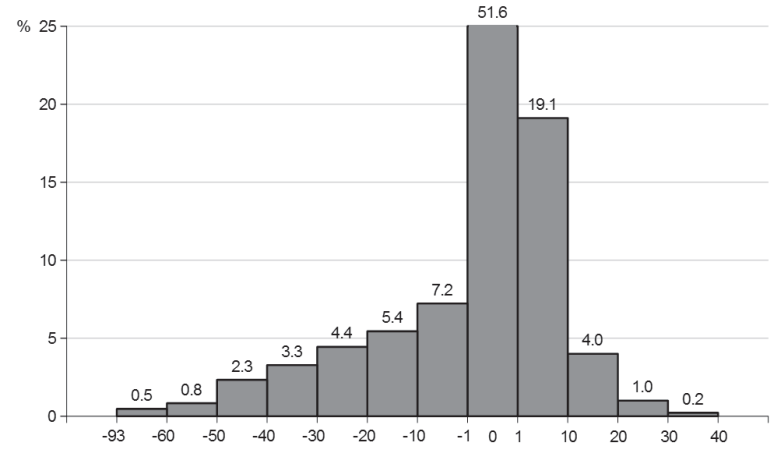

Figure 4. Distribution of the differences between SSL and reference sealing.

the reference data and SSL. Cells with an overestimation of imperviousness are more numerous than underestimated cells. Underestimation occurs primarily for the $0 \%$ sealing class (nonsealing cells). In fact, there are fewer cells with no impervious areas than cells with lots of impervious areas.

Over $80 \%$ of the misclassified cells were over- or underestimated by less than $10 \%$, which proves to be a satisfactory result. This leads to the conclusion, however, that the Soil Sealing Enhancement classification mainly overestimated the imperviousness of the area. Thus, a SSL value can be treated as the maximum sealing value of the tested area, especially for values of imperviousness over $30 \%$. Both underestimation and overestimation may occur for low sealing values. Another advantage of the analysed product is the continuous estimation of imperviousness from 0 to $100 \%$. 
Arnold, C \& Gibbons, C 1996, 'Impervious surface coverage: the emergence of a key environmental indicator' Journal of the American Planning Association, 62(2), pp. 243-258.

Atkinson, P, Foody, G \& Curran, P 2000, 'Assessing the ground data requirements for regional-scale remote sensing' International Journal of Remote Sensing, pp. 2571-2587.

Bauer, M, Heinert, N, Doyle, J, \& Fei, Y 2004, Impervious surface mapping and change monitoring using Landsat remote sensing, ASPRS - 70 years if service to the profession, Denver, Colorado.

Borowiec, N \& Hamerla A 2013, 'Porównanie metod oceny stopnia uszczelnienia terenu na podstawie ortofotomapy oraz danych lidarowych', Journal of Sustainable Mining, vol. 12, pp. 20-27.

Congalton, R \& Green, K 1993, 'A Practical Look at the Sources of Confusion in Error Matrix Generation', Photogrammetric Engineering \& Remote Sensing, vol. 59 (5), pp. 641-644.

Copernicus Land Monitoring Services, http://land. copernicus.eu/sandbox/test/imperviousness/ imperviousness-2009. [30 January 2014].

Drzewiecki, W \& Wróbel A 2007, 'Ocena wiarygodności fotointerpretacji powierzchni nieprzepuszczalnych na wysokorozdzielczych obrazach satelitarnych', Archiwum Fotogrametrii, Kartografii i Teledetekcji, vol. 17a, pp. 171178.

Edwards, T \& Moisen, G 1998, 'Assessing map accuracy in a remotely sensed, ecoregion-scale cover map', Remote Sensing of Environment, vol. 63, pp. 73- 83.

EEA, 2005, 'Land Cover Classification System, FAO', Rome.

EEA, 2006, 'Tender Specifications, GMES Fast Track Service on Land Monitoring, High Resolution Core Land Cover Data for Built-up Areas, Including Degree of Soil Sealing. EEA/ IDS/07/001. http://www.eea.europa.eu/about-us/tenders/ EEAIDS07001/tender_specifications.pdf. [30 January 2014].

EEA, 2015, 'Imperviousness and imperviousness change'. http://www.eea.europa.eu/data-and-maps/indicators/ imperviousness-change/assessment. [30 January 2014].

Flinker, P 2010, The Need to Reduce Impervious Cover to Prevent Flooding and Protect Water Quality, Rhode Island Department of Environmental Management, Rhode Island.

Foody, G 2002, 'Status of land cover classifications accuracy assessment', Remote Sensing of Environment, vol. 80, pp. 185-201.

Foody, G 2008, 'Harshness in image classification accuracy assessment', International Journal of Remote Sensing, vol. 29, pp. 3137-3158.
Grimmond, G 1998, 'Heat Storage in Urban Areas: Local-Scale Observations and Evaluation of a Simple Model', Journal of Applied Meteorology, vol. 38, pp. 922-925.

Hurbanek, P, Atkinson, P, Pazur, R, Rosina, K 2010a, 'Accuracy of built-up area mapping in Europe from the perspective of population surface modelling', European Forum for Geostatistics, Tallinn.

Hurbanek, P, Atkinson, P, Pazur, R, Rosina, K, Chockalingam $\mathrm{J}, 2010 \mathrm{~b}$, 'Accuracy of Built-up Area Mapping in Europe at Varying Scales and Thresholds', Accuracy 2010 Symposium, July 20-23, Leicester, UK [available from: http://www. spatial-accuracy.org/system/files/img-X07133558_0.pdf]. [30 January 2014]

Iwaniak, A, Krówczyńska, M \& Paluszyński, W 2002, 'Użycie sieci neuronowych do klasyfikacji obszarów miejskich na zdjęciach satelitarnych', Geodesia et Desciptio Terrarum, vol. 1 (1-2), pp. 5-13.

Johnson, MP 2001, 'Environmental Impacts of Urban Sprawl: A Survey of the Literature and Proposed Research Agenda', Environ Plan A, vol. 33 (4), pp. 717-735.

Maucha, G \& Buttner, G 2008, 'Recommendations. Quantitative assessment. High-resolution soil sealing layer, v. 2.1.'. European Environment Agency and European Topic Centre for Land Use and Spatial Information, pp. 1-31.

Maucha, G, Buttner, G \& Kosztra, B 2010, European validation of GMES FTS Soil Sealing Enhancement data, Barcelona: European Topic Center.

Oke, T 1973, 'City size and the urban heat island', Atmospheric Environment, vol. 7, pp. 769-772.

Polish National Geoportal, http://geoportal.gov.pl/ [31 January 2014]. Scepan, J 1999, 'Thematic Validation of High-Resolution Global Land-Cover Data Sets', Photogrammetric Engineering \& Remote Sensing, vol. 65 (9), pp. 1051-1060.

Skotnicki, M \& Sowiński, M 2011, 'Dokładność odwzorowania stopnia uszczelnienia zlewni cząstkowych w modelowaniu odpływu ze zlewni miejskiej', Gaz, Woda i Technika Sanitarna, vol. 7-8, pp. 276-279.

Stocker, J 1998, 'Methods of measuring and estimating impervious surfaces coverage', Nonpoint Education for Municipal Officials, technical paper no.3, University of Connecticut.

Weng, Q 2011, 'Remote sensing of impervious surfaces in the urban areas: Requirements, methods and trends', Remote Sensing of Environment, vol. 117, pp. 34-49. 